Miller, E., Sprague, J. M., Kissinger, L. W. \& McBurney, L. F. (1940). J. Amer. chem. Soc. 62, 2099.

Mitchell, G. A. G., Rees, W. S. \& Robinson, P. N. (1944). Lancet, 1, 627.

Otto, R. (1885). Ber. dtsch. chem. Ges. 18, 161.

Pugh, C. E. H. \& Quastel, J. H. (1937). Biochem. J. 31, 2306.

Remsen, J. \& Palmer, C. (1882). Amer. chem. J. 4, 142.

Richter, D. (1937). Biochem. J. 31, 2022.

Richter, D. (1938). Biochem. J. 32, 1763.

Richter, D., Lee, M. H. \& Hill, D. (1941). Biochem. J. 35, 1215.
Rogers, H. J. \& Knight, B. C. J. G. (1946). Biochem. J. 40, 400.

Schmith, K. (1943). Acta path. microbiol. Scand. 20, 563.

Schoop, G. \& Stoltz, A. (1941). Dtsch. tierärztl. Wschr. 49, 153.

Siebenmann, C. O. \& Plummer, H. (1945). J. Pharmacol. 83, 71.

Smiles, S. \& Stewart, J. (1921). J. chem. Soc. 119, 1797.

Ullmann, F. \& Pasdermadjian, G. (1901). Ber. dtsch. chem. Ges. 34, 1151.

Walker, C. (1897). Amer. chem. J. 19, 578.

Williams, R. T. (1938). Biochem. J. 32, 878.

\title{
The Fate of Certain Organic Acids and Amides in the Rabbit
}

\author{
2. $p$-HYDROXYBENZOIC ACID AND ITS AMIDE
}

\author{
By H. G. BRAY, BRENDA E. RYMAN AND W. V. THORPE, Department of Physiology, \\ Medical School, University of Birmingham
}

(Received 22 November 1946)

Continuing our investigation of the fate of the carboxylic acid amide grouping in the rabbit we have studied the metabolism of $p$-hydroxybenzoic acid and its amide. There are several metabolic changes, involving either the hydroxyl or carboxyl group, which these compounds might undergo. In the case of the amide the carboxyl group could be formed by hydrolysis, cf. benzamide (Bray, Neale \& Thorpe, 1946a). The hydroxyl group might be conjugated with either glucuronic or sulphuric acid and the carboxyl group with glucuronic acid or with glycine. It is also possible that a second hydroxyl group may be introduced, as with salicylic acid, which Lutwak-Mann (1943) found to give rise in the rat to gentisic acid (2:5-dihydroxybenzoic acid), and with $p$-hydroxybenzenesulphonamide, $4-5 \%$ of which was shown in this laboratory to be converted to 1:2-dihydroxybenzene-4-sulphonamide in the rabbit (Williams, 1941).

The metabolism of $p$-hydroxybenzoic acid has been studied by several workers, since it is a possible product of the putrefactive action of bacteria in the large intestine on tyrosine. Baumann \& Herter (1877) showed that it caused an increase in ethereal sulphate excretion when administered to dogs. Schotten (1882) found that it gave rise to $p$-hydroxyhippuric acid in man, $16 \%$ of a $26 \mathrm{~g}$. dose being excreted in this form and $35 \%$ unchanged. Quick $(1932 a, b)$ also studied this aspect of its metabolism and isolated from the urine of dogs receiving the acid a diglucuronide of $p$-hydroxybenzoic acid, both available groups being conjugated. Sherwin (1918) and Power \& Sherwin (1927), however, found that in both man and the monkey the acid was excreted largely unchanged. The metabolism of the amide does not appear to have been investigated except in so far as it was included in a study of the sulphate conjugation of various derivatives of phenol by Williams (1938).

In this investigation we have examined quantitatively the excretion of free $p$-hydroxybenzoic acid, and its conjugates with glycine, sulphuric acid and glucuronic acid, the latter as ester or ether glucuronides. The amide has been similarly studied in order to estimate the extent to which the amide group can be hydrolyzed in vivo. We have shown that it is possible to obtain extracts of rabbit liver which are capable of hydrolyzing some aromatic amides, and the effect of nuclear substituents on this reaction is being studied. This work will be reported separately, but reference will be made in this paper to some relevant experiments. Various qualitative aspects of the metabolism of the acid and amide have also been investigated, including the isolation of protocatechuic acid and 4-carbamylphenylglucuronide from the urine of rabbits dosed with the amide. Protocatechuic acid is also present, though in smaller amounts, in the urine of rabbits receiving $p$-hydroxybenzoic acid.

\section{METHODS}

Diet and feeding. These were as described in an earlier paper (Bray et al. 1946a). The rabbits used for some of the qualitative experiments received a diet of rabbit pellets 70 g. per diem (diet no. 18, Bruce \& Parkes, 1946) with water ad libitum. The acid was given by stomach tube as a solution of its sodium salt and the amide similarly, as a suspension in water. Five dose levels were used, viz. 
$.0 \cdot 1,0 \cdot 25,0.5,1 \cdot 0$ and $1.5 \mathrm{~g} . / \mathrm{kg}$. In no case was any toxic effect observed.

Preparation of p-hydroxybenzamide. Methyl $p$-hydroxybenzoate (10 g.) was heated with ammonia (10 ml. S.G. 0.88 ) in a sealed tube at $130-140^{\circ}$ for $8-10 \mathrm{hr}$. (cf. Hartmann, 1877). The product, a brown syrup which readily crystallized, was recrystallized from water and gave a monohydrate melting indefinitely at $90-110^{\circ}$, depending on the rate of heating. Above its melting-point this compound lost water, forming the anhydrous amide which melted at $161-162^{\circ}$. The average yield was $50 \%$ of the ester used. Considerable decarboxylation occurred during the preparation, phenol and ammonium carbonate being formed.

Preparation of p-hydroxyhippuric acid. This compound was prepared by the method of Fischer (1908) from glycine ester and $p$-methylcarbonatobenzoyl chloride. The product crystallized from ethanol-ether, melted at $240^{\circ}$ after sintering at $236^{\circ}$. Attempts to prepare this compound by diazotization of $p$-aminohippuric acid and subsequent decomposition of the diazonium compound were unsuccessful.

Estimation of p-hydroxybenzoic and p-hydroxyhippuric acids. The method used was essentially that described by Quick (1932a) for substituted benzoic acids, in which the ether-soluble material from urine is fractionated by means of toluene into the unconjugated acid, which in general is soluble in toluene, and the glycine conjugate, which is insoluble. In a later paper (Quick, 1932b) it is stated, however, that this procedure is not applicable to $p$-hydroxybenzoic acid unless the amounts to be estimated are very small, as the acid is not readily soluble in toluene, and a method is recommended involving separate estimation of the total phenol and of glycine. This was too lengthy for our purpose, but we found that we could adapt Quick's earlier method so that quantitative separation of the ethersoluble acid by toluene could be achieved. Control experiments, in which mixtures of known amounts of the two acids were extracted from water or normal rabbit urine, gave, in 16 estimations, average recoveries corresponding to $98 \%$ of the total acid, $95 \%$ of the $p$-hydroxybenzoic acid and $101 \%$ of the $p$-hydroxyhippuric acid.

Urine $\left(20 \mathrm{ml}\right.$.), acidified with $2 \mathrm{~N}-\mathrm{H}_{2} \mathrm{SO}_{4}(2 \mathrm{ml}$.), was continuously extracted with ether for $6 \mathrm{hr}$. The ether extract was then evaporated to dryness in vacuo, it being essential to dry the residue completely before extracting with toluene. This process was carried out by refluxing the residue with successive amounts of toluene $(20 \mathrm{ml}$. for $45 \mathrm{~min}$., followed by three consecutive volumes of $10 \mathrm{ml}$. for 20 min., decanting each time). The completeness of the extraction was checked by separate evaporation and titration of the last extract. The three extracts were combined and evaporated to dryness in vacuo below $50^{\circ}$. The solid residues (toluene-soluble and toluene-insoluble) were separately dissolved in water $(20 \mathrm{ml}$.) and titrated with $0.02 \mathrm{~N}-\mathrm{NaOH}$ to $\mathrm{pH} 7 \cdot 8$, using phenol red as indicator. It was found advisable to modify the method slightly when estimating the acids in urines passed during the first $24 \mathrm{hr}$. after a large dose of $p$-hydroxybenzoic acid. The daily volume was diluted to $450-500 \mathrm{ml}$. and only $10 \mathrm{ml}$. used for the estimation. Control experiments showed that the presence of $p$-hydroxybenzamide does not affect the estimation of ether-soluble acids by this method.

The estimation of ethereal sulphate and reducing substances (i.e. ester and ether type glucuronides) was carried out as described previously (Bray et al. 1946a,b). In the last estimation, control experiments showed that $90 \mathrm{~min}$. hydrolysis was sufficient for complete liberation of the glucuronic acid present as ether type glucuronide.

\section{RESULTS}

\section{Quantitative studies}

Ether-soluble acid excretion. The average 'baseline' values ranged as before from 287 to $370 \mathrm{mg}$. (Bray et al. 1946a). Extraction of the ether-soluble acid with toluene as described above removed $74-80 \%$ of the total. This was greater than when light petroleum was used for the extraction (Bray et $a$ l. $1946 a$ ), when only $10-25 \%$ was removed. The nature of the normal ether-soluble acid of rabbit urine is unknown.

Table 1 shows the percentages of the doses excreted as ether-soluble acid, soluble in toluene (calculated as $p$-hydroxybenzoic acid) and as ethersoluble acid insoluble in toluene (calculated as $p$ hydroxyhippuric acid). In the case of the amide some of the results represent the total (i.e. unfractionated) acid. In every case the excretion of ether-soluble acid in the second $24 \mathrm{hr}$. after the dose was normal.

Ethereal sulphate excretion. The normal range of the daily output of ethereal sulphate of the rabbits used in this investigation was $10-38 \mathrm{mg} . \mathrm{SO}_{3}$, average values for individual rabbits ranging from 16 to $27 \mathrm{mg}$. Table 2 shows the percentages of doses of acid and amide excreted conjugated with ethereal sulphate, assuming that conjugation of these compounds was the sole cause of the increase of ethereal sulphate excretion observed. The increase in ethereal sulphate excretion did not persist after $24 \mathrm{hr}$. from the time of dosing.

Excretion of reducing substances. The average normal daily output ranged from 139 to $229 \mathrm{mg}$. (calculated as glucuronic acid). These values were found to increase on acid hydrolysis as previously described, but it is now evident that the actual percentage increase may vary considerably, average values in the experiments described here corresponding to $39 \%$ of the unhydrolyzed value (range $35-40 \%$ ). Table 3 shows the percentage of the doses excreted conjugated with glucuronic acid as ester and ether type glucuronides, assuming the increase in reducing values observed to be due entirely to the excretion of these compounds. The amount of reducing material excreted returned to within the normal range during the second $24 \mathrm{hr}$. after dosing.

Enzyme studies. We have been able to show that extracts of rabbit liver, the preparation of which will be described in a separate paper, are capable of hydrolyzing amides. The extent of hydrolysis can be estimated by a formol titration based upon that 
described by Northrop (1932) and Balls \& Lineweaver (1939). Benzamide is hydrolyzed to the extent of $50-60 \%$ of a $0.02 \mathrm{M}$ solution in $48 \mathrm{hr}$. and $p$-nitrobenzamide to the extent of $50-70 \%$ of a $0.02 \mathrm{M}$ solution in $5 \mathrm{hr}$. In three out of four experiments with $p$-hydroxybenzamide, carried out under exactly similar conditions, no detectable splitting occurred, while in the fourth $15 \%$ was hydrolyzed in $48 \mathrm{hr}$. These studies are being continued with a view to determining the effect of substituents and their position in the benzenoid ring, on the stability of amides to enzymic hydrolysis.

Table 1. Excretion of ether-soluble acid (calculated as $\mathrm{p}$-hydroxybenzoic and $\mathrm{p}$-hydroxyhippuric acids) after doses of $\mathrm{p}$-hydroxybenzoic acid and $\mathrm{p}$-hydroxybenzamide

\begin{tabular}{|c|c|c|c|c|c|}
\hline \multirow[b]{2}{*}{$\begin{array}{c}\text { Exp. } \\
\text { no. }\end{array}$} & \multirow{3}{*}{ Rabbit } & & \multicolumn{3}{|c|}{ Percentage of dose excreted as } \\
\hline & & $\begin{array}{c}\text { Approx. } \\
\text { dose } \\
\text { level } \\
\text { (g./kg.) }\end{array}$ & $\begin{array}{c}p- \\
\text { Hydroxy- } \\
\text { benzoic } \\
\text { acid }\end{array}$ & 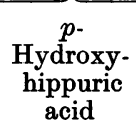 & $\begin{array}{c}\text { Total } \\
\text { ether- } \\
\text { soluble } \\
\text { acid }\end{array}$ \\
\hline \multicolumn{5}{|c|}{$p$-Hydroxybenzoic acid } & \\
\hline $\begin{array}{l}27 \\
23 \\
14 \\
24 \\
13\end{array}$ & $\begin{array}{l}102 \\
118 \\
119 \\
119 \\
120\end{array}$ & $\begin{array}{l}0 \cdot 1 \\
0 \cdot 1 \\
0 \cdot 1 \\
0 \cdot 1 \\
0 \cdot 1\end{array}$ & $\begin{array}{l}28 \\
54 \\
21 \\
25 \\
37\end{array}$ & $\begin{array}{l}29 \\
18 \\
34 \\
29 \\
43\end{array}$ & $\begin{array}{l}\mathbf{5 7} \\
\mathbf{7 2} \\
\mathbf{5 5} \\
\mathbf{5 4} \\
\mathbf{8 0}\end{array}$ \\
\hline $\begin{array}{r}15 \\
26 \\
20 \\
30 \\
9 \\
17\end{array}$ & $\begin{array}{l}102 \\
102 \\
118 \\
118 \\
119 \\
120\end{array}$ & $\begin{array}{l}0 \cdot 25 \\
0 \cdot 25 \\
0 \cdot 25 \\
0 \cdot 25 \\
0 \cdot 25 \\
0 \cdot 25\end{array}$ & $\begin{array}{l}40 \\
47 \\
41 \\
54 \\
49 \\
40\end{array}$ & $\begin{array}{l}19 \\
16 \\
30 \\
13 \\
21 \\
23\end{array}$ & $\begin{array}{l}59 \\
63 \\
71 \\
67 \\
70 \\
63\end{array}$ \\
\hline $\begin{array}{r}8 \\
7 \\
16 \\
29 \\
11 \\
21 \\
22\end{array}$ & $\begin{array}{l}102 \\
118 \\
118 \\
119 \\
120 \\
120 \\
120\end{array}$ & $\begin{array}{l}0.5 \\
0.5 \\
0.5 \\
0.5 \\
0.5 \\
0.5 \\
0.5\end{array}$ & $\begin{array}{l}64 \\
74 \\
65 \\
72 \\
34 \\
56 \\
70\end{array}$ & $\begin{array}{r}16 \\
17 \\
20 \\
17 \\
6 \\
12 \\
6\end{array}$ & $\begin{array}{l}80 \\
91 \\
85 \\
89 \\
40 \\
68 \\
76\end{array}$ \\
\hline $\begin{array}{r}10 \\
5 \\
6 \\
18 \\
12\end{array}$ & $\begin{array}{l}102 \\
118 \\
119 \\
119 \\
120\end{array}$ & $\begin{array}{l}1.0 \\
1.0 \\
1 \cdot 0 \\
1.0 \\
1.0\end{array}$ & $\begin{array}{l}49 \\
57 \\
45 \\
32 \\
68\end{array}$ & $\begin{array}{l}15 \\
16 \\
33 \\
26 \\
17\end{array}$ & $\begin{array}{l}64 \\
71 \\
78 \\
58 \\
85\end{array}$ \\
\hline $\begin{array}{l}19 \\
25 \\
24 \\
22\end{array}$ & $\begin{array}{l}102 \\
102 \\
119 \\
120\end{array}$ & $\begin{array}{r}1.5 \\
1.5 \\
1.5 \\
1.5\end{array}$ & $\begin{array}{l}42 \\
47 \\
35 \\
53\end{array}$ & $\begin{array}{l}20 \\
17 \\
24 \\
17\end{array}$ & $\begin{array}{l}62 \\
64 \\
59 \\
70\end{array}$ \\
\hline \multicolumn{6}{|c|}{$p$-Hydroxybenzamide } \\
\hline $\begin{array}{l}45 \\
36 \\
43 \\
37\end{array}$ & $\begin{array}{l}102 \\
118 \\
119 \\
120\end{array}$ & $\begin{array}{l}0 \cdot 1 \\
0 \cdot 1 \\
0 \cdot 1 \\
0 \cdot 1\end{array}$ & 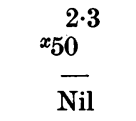 & $\frac{\mathrm{Nil}}{\mathrm{Nil}}$ & $\begin{array}{c}3 \cdot 5 \\
x 50 \\
x_{48} \\
\text { Nil }\end{array}$ \\
\hline $\begin{array}{l}32 \\
42 \\
49\end{array}$ & $\begin{array}{l}102 \\
102 \\
119\end{array}$ & $\begin{array}{l}0 \cdot 25 \\
0 \cdot 25 \\
0 \cdot 25\end{array}$ & $\frac{\mathrm{Nil}}{\mathrm{Nil}}$ & $\frac{\mathrm{Nil}}{\mathrm{Nil}}$ & $\begin{array}{c}\mathrm{Nil} \\
x_{22} \\
\mathrm{Nil}\end{array}$ \\
\hline $\begin{array}{l}44 \\
48 \\
46 \\
33\end{array}$ & $\begin{array}{l}102 \\
118 \\
119 \\
120\end{array}$ & $\begin{array}{l}0.5 \\
0.5 \\
0.5 \\
0.5\end{array}$ & $\begin{array}{c}12 \\
2 \cdot 8 \\
7 \cdot 3\end{array}$ & $\begin{array}{c}\overline{\mathrm{Nil}} \\
4 \cdot 6 \\
\mathrm{Nil}\end{array}$ & $\begin{array}{c}\text { Nil } \\
12 \\
7 \cdot 4 \\
7 \cdot 3\end{array}$ \\
\hline
\end{tabular}

Table 1 (cont.).

\begin{tabular}{|c|c|c|c|c|c|}
\hline \multirow[b]{2}{*}{$\begin{array}{c}\text { Exp. } \\
\text { no. }\end{array}$} & \multirow[b]{2}{*}{ Rabbit } & \multirow[b]{2}{*}{$\begin{array}{c}\text { Approx. } \\
\text { dose } \\
\text { level } \\
\text { (g./kg.) }\end{array}$} & \multicolumn{3}{|c|}{ Percentage of dose excreted a } \\
\hline & & & $\begin{array}{c}p- \\
\text { Hydroxy- } \\
\text { benzoic } \\
\text { acid }\end{array}$ & $\begin{array}{c}p- \\
\text { Hydroxy- } \\
\text { hippuric } \\
\text { acid }\end{array}$ & $\begin{array}{c}\text { Total } \\
\text { ether- } \\
\text { soluble } \\
\text { acid }\end{array}$ \\
\hline 35 & 102 & $1 \cdot 0$ & $1 \cdot 0$ & $1 \cdot 8$ & $2 \cdot 8$ \\
\hline 45 & 102 & $1 \cdot 0$ & - & - & $\mathrm{Nil}$ \\
\hline 50 & 102 & $1 \cdot 0$ & $2 \cdot 3$ & $1 \cdot 2$ & $3 \cdot 5$ \\
\hline 34 & 119 & 1.0 & $3 \cdot 1$ & $1 \cdot 6$ & $4 \cdot 7$ \\
\hline 47 & 120 & $1 \cdot 0$ & - & - & $4 \cdot 9$ \\
\hline 39 & 102 & 1.5 & $2 \cdot 0$ & $1 \cdot 8$ & $3 \cdot 8$ \\
\hline 38 & 119 & 1.5 & $2 \cdot 5$ & $1 \cdot 0$ & 3.5 \\
\hline 51 & 119 & 1.5 & - & - & $5 \cdot 9$ \\
\hline 52 & 119 & 1.5 & - & - & $2 \cdot 7$ \\
\hline 44 & 120 & 1.5 & 一 & - & $3 \cdot 7$ \\
\hline
\end{tabular}

(1) Experiment numbers in Tables 1, 2 and 3 enable results obtained from the same experiment to be correlated.

(2) The results marked $x$ at the lower dose levels are considered to be abnormally high and are omitted from the averages in Table 4. In these cases the actual amounts of the various metabolites excreted were usually within the normal range, although actually above the base-line used. Even such small increases represent a large percentage of doses of 200-500 mg.

(3) The conjugation of any protocatechuic acid formed is ignored since the amounts excreted are very small.

Table 2. Percentage of doses of $\mathrm{p}-$ hydroxybenzoic acid and $\mathrm{p}$-hydroxybenzamide excreted conjugated with ethereal sulphate

\begin{tabular}{|c|c|c|c|}
\hline \\
\hline $\begin{array}{c}\text { Exp. } \\
\text { no. }\end{array}$ & Rabbit & $\begin{array}{l}\text { Approx. } \\
\text { dose } \\
\text { level } \\
\text { (g./kg.) }\end{array}$ & $\begin{array}{c}\text { Percentage } \\
\text { excreted as } \\
\text { ethereal } \\
\text { sulphate }\end{array}$ \\
\hline \multicolumn{4}{|c|}{$p$-Hydroxybenzoic acid } \\
\hline $\begin{array}{r}1 \\
4 \\
10 \\
25\end{array}$ & $\begin{array}{l}102 \\
102 \\
102 \\
102\end{array}$ & $\begin{array}{l}0.5 \\
0.5 \\
1.0 \\
1.5\end{array}$ & $\begin{array}{l}7 \cdot 1 \\
6 \cdot 2 \\
6 \cdot 1 \\
4 \cdot 4\end{array}$ \\
\hline 30 & 118 & $0 \cdot 25$ & $6 \cdot 2$ \\
\hline $\begin{array}{r}3 \\
2 \\
24\end{array}$ & $\begin{array}{l}119 \\
119 \\
119\end{array}$ & $\begin{array}{l}0.1 \\
0.25 \\
1.5\end{array}$ & $\begin{array}{l}3 \cdot 7 \\
8 \cdot 3 \\
7 \cdot 4\end{array}$ \\
\hline $\begin{array}{l}12 \\
53\end{array}$ & $\begin{array}{l}120 \\
120\end{array}$ & $\begin{array}{l}1.0 \\
1.5\end{array}$ & $\begin{array}{l}4 \cdot 5 \\
3 \cdot 7\end{array}$ \\
\hline \multicolumn{4}{|c|}{$p$-Hydroxybenzamide } \\
\hline $\begin{array}{l}42 \\
41 \\
35 \\
39\end{array}$ & $\begin{array}{l}102 \\
102 \\
102 \\
102\end{array}$ & $\begin{array}{l}0.25 \\
0.5 \\
1.0 \\
1.5\end{array}$ & $\begin{array}{l}21 \cdot 9 \\
19 \cdot 1 \\
17 \cdot 1 \\
13 \cdot 9\end{array}$ \\
\hline $\begin{array}{l}32 \\
40\end{array}$ & $\begin{array}{l}118 \\
118\end{array}$ & $\begin{array}{l}0.5 \\
1.0\end{array}$ & $\begin{array}{l}15 \cdot 0 \\
16 \cdot 8\end{array}$ \\
\hline $\begin{array}{l}43 \\
31 \\
38\end{array}$ & $\begin{array}{l}119 \\
119 \\
119\end{array}$ & $\begin{array}{l}0 \cdot 1 \\
0 \cdot 25 \\
1 \cdot 5\end{array}$ & $\begin{array}{l}26 \cdot 3 \\
23 \cdot 6 \\
13 \cdot 7\end{array}$ \\
\hline 37 & 120 & $0 \cdot 1$ & $43 \cdot 1$ \\
\hline
\end{tabular}

See footnote to Table 1. 
Table 3. Percentage of doses of p-hydroxybenzoic acid and its amide excreted as ether and ester type glucuronides

\begin{tabular}{|c|c|c|c|c|}
\hline \multirow[b]{2}{*}{$\begin{array}{l}\text { Exp. } \\
\text { no. }\end{array}$} & \multirow[b]{2}{*}{ Rabbit } & \multirow{2}{*}{$\begin{array}{c}\text { Approx. } \\
\text { dose } \\
\text { level } \\
\text { (g./kg.) }\end{array}$} & \multicolumn{2}{|c|}{$\begin{array}{l}\text { Percentage of dose } \\
\text { excreted as }\end{array}$} \\
\hline & & & $\begin{array}{c}\text { Ester } \\
\text { glucuronide }\end{array}$ & $\begin{array}{c}\text { Ether } \\
\text { glucuronide }\end{array}$ \\
\hline \multicolumn{5}{|c|}{$p$-Hydroxybenzoic acid } \\
\hline $\begin{array}{r}1 \\
4 \\
10 \\
25\end{array}$ & $\begin{array}{l}102 \\
102 \\
102 \\
102\end{array}$ & $\begin{array}{l}0.5 \\
0.5 \\
1.0 \\
1.5\end{array}$ & $\begin{array}{r}3 \cdot 5 \\
15 \cdot 1 \\
6 \cdot 1 \\
6 \cdot 6\end{array}$ & $\begin{array}{c}7 \cdot 8 \\
\text { Nil } \\
13 \cdot 3 \\
14 \cdot 1\end{array}$ \\
\hline $\begin{array}{r}3 \\
2 \\
24\end{array}$ & $\begin{array}{l}119 \\
119 \\
119\end{array}$ & $\begin{array}{l}0 \cdot 1 \\
0 \cdot 25 \\
1 \cdot 5\end{array}$ & $\begin{array}{r}16 \cdot 3 \\
5 \cdot 0 \\
11 \cdot 0\end{array}$ & $\begin{array}{r}18 \cdot 6 \\
9 \cdot 5 \\
\text { Nil }\end{array}$ \\
\hline $\begin{array}{l}22 \\
12 \\
53\end{array}$ & $\begin{array}{l}120 \\
120 \\
120\end{array}$ & $\begin{array}{l}0.5 \\
1.0 \\
1.5\end{array}$ & $\begin{array}{l}5 \cdot 0 \\
5 \cdot 2 \\
1 \cdot 8\end{array}$ & $\begin{array}{r}4 \cdot 7 \\
11 \cdot 0 \\
10 \cdot 5\end{array}$ \\
\hline \multicolumn{5}{|c|}{$p$-Hydroxybenzamide } \\
\hline $\begin{array}{l}42 \\
41 \\
35 \\
39\end{array}$ & $\begin{array}{l}102 \\
102 \\
102 \\
102\end{array}$ & $\begin{array}{l}0.25 \\
0.5 \\
1.0 \\
1.5\end{array}$ & $\begin{array}{l}\text { Nil } \\
\text { Nil } \\
\text { Nil } \\
\text { Nil }\end{array}$ & $\begin{array}{l}15 \cdot 1 \\
15 \cdot 4 \\
18 \cdot 0 \\
20 \cdot 2\end{array}$ \\
\hline $\begin{array}{l}36 \\
40\end{array}$ & $\begin{array}{l}118 \\
118\end{array}$ & $\begin{array}{l}0 \cdot 1 \\
1 \cdot 5\end{array}$ & $\begin{array}{c}\mathrm{Nil} \\
2 \cdot 8\end{array}$ & $\begin{array}{c}\mathrm{Nil} \\
23 \cdot 8\end{array}$ \\
\hline $\begin{array}{l}43 \\
31 \\
34\end{array}$ & $\begin{array}{l}119 \\
119 \\
119\end{array}$ & $\begin{array}{l}0 \cdot 1 \\
0 \cdot 25 \\
1 \cdot 0\end{array}$ & $\begin{array}{c}\mathrm{Nil} \\
\mathrm{Nil} \\
2 \cdot 5\end{array}$ & $\begin{array}{c}\text { Nil } \\
15 \cdot 6 \\
29 \cdot 3\end{array}$ \\
\hline 37 & 120 & $0 \cdot 1$ & Nil & ${ }^{x} 45 \cdot 1$ \\
\hline
\end{tabular}

See footnote to Table 1.

\section{Qualitative studies}

\section{Isolation of p-hydroxybenzoic and p-hydroxyhippuric acids}

The urine passed by rabbits during $24 \mathrm{hr}$. after they had received $p$-hydroxybenzoic acid $(1 \mathrm{~g}$. $/ \mathrm{kg}$.) was acidified (approx. $10 \mathrm{ml} .2 \mathrm{~N}-\mathrm{H}_{2} \mathrm{SO}_{4} / 100 \mathrm{ml}$. urine) and continuously extracted with ether for $24 \mathrm{hr}$. The extract was evaporated to dryness and extracted repeatedly with boiling toluene. The two fractions were purified as follows.

Toluene soluble fraction. The solvent was removed in vacuo and the residual syrup dissolved in water and treated with charcoal. The colourless filtrate deposited rosettes of white needles which melted at $207-209^{\circ}$. After two recrystallizations from water the melting-point was $214^{\circ}$ alone or in admixture with an authentic sample of $p$-hydroxybenzoic acid (m.p. 214 ${ }^{\circ}$.

Residue after toluene extraction. The brown residue was dissolved in water and decolorized by treatment with charcoal. The crystals obtained by evaporation of the filtrate melted at $215-216^{\circ}$ and still contained an appreciable amount of $p$-hydroxybenzoic acid. This was removed by further extraction with toluene. The residue from this extraction, after recrystallization from water, melted at $239-240^{\circ}$ with decomposition. A mixed melting-point with an authentic specimen of $p$-hydroxyhippuric acid (m.p. $240^{\circ}$ ) was $238-239^{\circ}$.

\section{Isolation of 3:4-dihydroxybenzoic acid (protocatechuic acid)}

This oxidation product was isolated from urine passed by rabbits which had received $p$-hydroxybenzamide. It was first detected in the urine of rabbits receiving the acid, being associated with the $p$-hydroxyhippuric acid fraction, but although this gave the characteristic bright green colour reaction with ferric chloride, crystalline specimens were only obtained from urine obtained after dosing with the amide. Such urine often gave a green colour with ferric chloride as collected. We were unable to separate protocatechuic acid from the other metabolites with which it was associated by fractional crystallization, but we were able to isolate it via its insoluble lead salt.

Urine from 10 rabbits which had been dosed with $p$-hydroxybenzamide (1.5 g. $/ \mathrm{kg}$.) was acidified $(2 \mathrm{ml}$. $2 \mathrm{~N}-\mathrm{H}_{2} \mathrm{SO}_{4} / 100 \mathrm{ml}$.) and continuously extracted with ether for $48 \mathrm{hr}$. The extract was evaporated to dryness and gave, in aqueous solution, a greenish coloration with ferric chloride. It was, however, shown that almost all the ether-soluble material was $p$-hydroxybenzamide which had been excreted unchanged. The small amount of protocatechuic acid present could not be isolated.

The urine after ether extraction was hydrolyzed by boiling for $20 \mathrm{~min}$. with $0.2 \mathrm{vol}$. conc. HCl, neutralized to congo red and continuously extracted with ether for $60 \mathrm{hr}$. The ether-soluble material, after removal of the solvent, was dissolved in water and decolorized with charcoal. On concentration of the filtrate a large crop of crystals was obtained. These were shown to consist of $p$-hydroxybenzoic acid, derived from the amide by the acid hydrolysis. The mother liquors, which gave an intense green colour with ferric chloride, were treated with lead acetate solution $(0.5 \mathrm{~N})$ until no further precipitation occurred. The precipitate was centrifuged off, suspended in water and decomposed with $\mathrm{H}_{2} \mathrm{~S}$. The filtrate from lead sulphide was evaporated to dryness and the residue repeatedly extracted with absolute ethanol. The combined extracts were evaporated to dryness and the resulting syrup dissolved in water. By gentle evaporation of this solution fine white needles were obtained, melting at $191^{\circ}$. Recrystallization from water raised the melting-point to 195-196 ${ }^{\circ}$. A mixed melting-point with an authentic specimen of protocatechuic acid (m.p. $199^{\circ}$ ) was $198^{\circ}$; yield $100 \mathrm{mg}$. from $30 \mathrm{~g}$. amide fed. The identity of the product was further confirmed by its conversion to the diacetyl derivative by refluxing for $15 \mathrm{~min}$. with acetic anhydride. The excess anhydride was decomposed with water, the solution 
concentrated and kept at $0^{\circ}$ overnight. White crystals separated which melted at $157^{\circ}$. A mixed melting-point with an authentio specimen of diacetylprotocatechuic acid (m.p. $157-158^{\circ}$ ) was 155-157.

The fact that protocatechuic acid could be isolated only after the ether-extracted urine had been hydrolyzed, suggests that it is excreted mainly in conjugated form, probably as the ethereal sulphate or ether-glucuronide of its amide, or, if the rabbit is able to hydrolyze protocatechuic acid amide, as an ethereal sulphate or an ester or ether glucuronide of protocatechuic acid. Since the amide group of $p$ hydroxybenzamide has been shown to be resistant to hydrolysis in the rabbit, it seems probable that protocatechuic acid amide is first formed, so that the nature of the conjugates excreted will depend on the stability of this amide in vivo.

\section{Isolation of 4-carbamylphenylglucuronide}

$p$-Hydroxybenzamide was administered to each of eight rabbits at a dose level of $1 \mathrm{~g}$. $/ \mathrm{kg}$. and the urine passed during the subsequent $24 \mathrm{hr}$. (3 l.) was collected and acidified with glacial acetic acid. Excess of saturated normal lead acetate solution was added and the resulting precipitate discarded. The filtrate was made alkaline by addition of ammonia and an excess of saturated basic lead acetate solution added. The precipitate was isolated, suspended in water (1 l.) and decomposed with $\mathrm{H}_{2} \mathrm{~S}$. The lead sulphide was filtered off and the filtrate evaporated to $100 \mathrm{ml}$. under reduced pressure at $50-60^{\circ}$. An excess of solid barium carbonate was stirred in, the mixture filtered and the residue washed with water. The combined filtrate and washings were precipitated by adding 5 vol. $96 \%$ ethanol (yield of crude barium salt, 20 g.).

This was dissolved in water and decolorized with charcoal. The filtrate crystallized on evaporation. The crystals obtained were too soluble to be re- crystallized from water and were purified by dissolving in aqueous ethanol and adding $96 \%$ ethanol to the solution. On chilling; rosettes of fine white needles separated (yield, 15 g.). These did not reduce Benedict's solution without preliminary hydrolysis with $2 \mathrm{~N}-\mathrm{HCl}$ and melted at $299-300^{\circ}$ with decomposition, $[\alpha]_{D}^{20^{\circ}}=-78^{\circ}$ (water). Found: C, 38.4; $\mathrm{H}, 4.0 ; \mathrm{N}, 3 \cdot 2 ; \mathrm{Ba}, 17 \cdot 1$; glucuronic acid (after $1 \mathrm{hr}$. hydrolysis with $2 \mathrm{~N}-\mathrm{HCl}$ ), $46.9 ; \mathrm{H}_{2} \mathrm{O}, 3.6 \%$. The barium salt of 4-carbamylphenylglucuronide. $\mathrm{C}_{26} \mathrm{H}_{28} \mathrm{O}_{16} \mathrm{~N}_{2} \mathrm{Ba}, 2 \mathrm{H}_{2} \mathrm{O}$ requires $\mathrm{C}, 39 \cdot 2 ; \mathrm{H}, 4 \cdot 0 ; \mathrm{N}, 3 \cdot 5$; $\mathrm{Ba}, 17 \cdot 2$; glucuronic acid, $48 \cdot 7 ; \mathrm{H}_{2} \mathrm{O}, 4.5 \%$.

$p$-Hydroxybenzoic acid was isolated from the compound by hydrolyzing with $2 \mathrm{~N}-\mathrm{HCl}$ and subsequent ether extraction. The presence of protocatechuic acid in the mixture obtained by hydrolyzing crude specimens of the barium salt suggests that it is excreted as a glucuronide in a way similar to $p$-hydroxybenzamide.

The free glucuronide was prepared from a solution of the barium salt by the careful addition of $2 \mathrm{~N}$ sulphuric acid until only a slight excess of barium remained. The barium sulphate formed was filtered off and the filtrate carefully evaporated. The glucuronide separated as large needles which were recrystallized from water (yield, 10 g.). It did not reduce Benedict's solution and melted at $212^{\circ}$ with decomposition, $[\alpha]_{20^{\circ}}^{D}=-93^{\circ}$ (water). (Found: C, $50 \cdot 2 ; \mathrm{H}, 4.9 ; \mathrm{N}, 4.2$; glucuronic acid, $61.3 \%$; equivalent (by titration), 308; ash, nil. $\mathrm{C}_{13} \mathrm{H}_{15} \mathrm{O}_{8} \mathrm{~N}$ requires $\mathrm{C}, 49.9 ; \mathrm{H}, 4.8 ; \mathrm{N}, 4.5$; glucuronic acid, $62.0 \%$; equivalent, 313 .)

\section{DISCUSSION}

Table 4 summarizes the quantitative results presented above. For the purpose of these calculations it is assumed that the glucuronides and ethereal sulphates formed are insoluble in ether, so that the ether-soluble acid estimated does not include these

Table 4. Metabolites of p-hydroxybenzoic acid and its amide in rabbit urine after administration

\begin{tabular}{|c|c|c|c|c|c|c|c|}
\hline \multirow[b]{2}{*}{$\begin{array}{l}\text { Dose level } \\
\text { (g. } / \mathrm{kg} .)\end{array}$} & \multicolumn{6}{|c|}{ Percentage of dose excreted as } & \multirow[b]{2}{*}{$\begin{array}{l}\text { Approx. } \\
\text { total \% } \\
\text { accounted } \\
\text { for }\end{array}$} \\
\hline & $\begin{array}{l}p \text {-Hydroxy- } \\
\text { benzoic } \\
\text { acid }\end{array}$ & $\begin{array}{l}p \text {-Hydroxy- } \\
\text { hippuric } \\
\text { acid }\end{array}$ & $\begin{array}{l}\text { Total ether- } \\
\text { soluble } \\
\text { acid }\end{array}$ & $\begin{array}{c}\text { Ester } \\
\text { glucuronide }\end{array}$ & $\begin{array}{c}\text { Ether } \\
\text { glucuronide }\end{array}$ & $\begin{array}{l}\text { Ethereal } \\
\text { sulphate }\end{array}$ & \\
\hline \multicolumn{8}{|c|}{ Acid } \\
\hline $0 \cdot 1$ & 35 & 31 & 66 & 16 & 19 & 4 & 105 \\
\hline $0 \cdot 25$ & 45 & $20^{\circ}$ & 65 & 5 & 10 & 7 & 87 \\
\hline 0.5 & 62 & 13 & 75 & 4 & 6 & 7 & 92 \\
\hline $1 \cdot 0$ & 52 & 21 & 73 & 6 & 12 & 5 & 96 \\
\hline 1.5 & 44 & 20 & 64 & 7 & 8 & 5 & 84 \\
\hline \multicolumn{7}{|c|}{ Amide } & $\begin{array}{l}\text { Approx. \% } \\
\text { hydrolyzed }\end{array}$ \\
\hline $0 \cdot 1$ & 1 & 1 & $\mathbf{2}$ & Nil & 15 & 35 & 2 \\
\hline 0.25 & Nil & Nil & Nil & $\mathrm{Nil}$ & 15 & 23 & Nil \\
\hline 0.5 & 4 & 2 & 7 & Nil & 15 & 17 & 7 \\
\hline 1.0 & 2 & 2 & 3 & 1 & 24 & 17 & 4 \\
\hline 1.5 & 2 & 1 & 5 & 1 & 22 & 14 & 6 \\
\hline
\end{tabular}


conjugates. Control experiments showed that the glucuronides, at any rate, are only sparingly soluble in ether. The conjugation of protocatechuic acid is also neglected, for the amount formed is very small, so that any errors due to the possibility that its two hydroxyl groups may be conjugated with sulphuric acid (Baumann \& Herter, 1877; Preússe, 1878) or with glucuronic acid (Marfori, 1897) are negligible. It is clear that the presence of a hydroxyl group in the para position stabilizes the amide group biologically, for the rabbit, which is able to hydrolyze benzamide (Bray et al. 1946a), cannot hydrolyze $p$-hydroxybenzamide. This is shown by the difference in the ethereal sulphate conjugation of the acid and amide, by the virtual absence of extra ether-soluble acid from the urine of rabbits receiving the amide, and by the absence of extra ester type glucuronide after amide feeding. The fact that more protocatechuic acid, chiefly in the form of a conjugate, is formed from $p$-hydroxybenzamide than from the acid is another indication that the two compounds are metabolized differently. These observations are supported by the in vitro experiments which show that rabbit liver extracts are able to hydrolyze the amide grouping in several amides, including benzamide, but not in $p$-hydroxybenzamide. This is an interesting example of change in response occasioned by slight structural change.

The oxidation product isolated is the one which would have been expected by analogy with the oxidation of other disubstituted aromatic compounds into which a hydroxyl group is introduced. It would appear to be a general rule that when para or meta substituted amino or hydroxy compounds are oxidized in this way the new hydroxyl group is introduced ortho to the amino or hydroxyl group. In the meta compounds the new group is para to the other (i.e. not amino or hydroxyl) substituent group and not meta as in the para substituted compounds, so that in either case the product is a 3:4-disub- stituted compound. Examples of such oxidations are given in Table 5. In the two ortho substituted hydroxy compounds quoted, the new hydroxyl group is inserted para, not ortho, to the existing hydroxyl group. It seems that ortho amino compounds behave still differently, since Jaffe \& Hilbert (1888) found that $o$-acetoluidide in dogs gave rise to a benzoxazolone derivative, presumably derived from 2-amino-3-hydroxytoluene. It will be of interest to see whether Williams (1945) can substantiate his suggestion that 0 -aminobenzenesulphonamide is oxidized to the vicinally substituted 2-amino-3-hydroxybenzenesulphonamide in the rabbit. We are investigating $o$ - and $m$-hydroxybenzoic acids and their amides and the aminobenzoic acids and amides. These studies may provide further examples of this type of oxidation.

\section{SUMMARY}

1. A study of the metabolism of $p$-hydroxybenzoic acid and its amide in the rabbit has been made.

2. Estimation of the excretion of ether-soluble acid ( $p$-hydroxybenzoic and $p$-hydroxyhippuric acid fractions), ester and ether type glucuronides and ethereal sulphate has provided evidence that the amide group in $p$-hydroxybenzamide is not hydrolyzed to any appreciable extent in vivo.

3. This conclusion is supported by enzyme studies.

4. Metabolites of the two compounds, which have been isolated from the urine of rabbits receiving them, are $p$-hydroxyhippuric acid from the acid and protocatechuic acid and 4-carbamylphenylglucuronide from the amide.

We are indebted to the Royal Society for a Government Grant which defrayed part of the cost of this work. The enzyme studies were carried out with the co-operation of Dr Sybil P. James. The micro-analyses were carried out by Drs Weiler and Strauss, Oxford.

Table 5. Configuration of hydroxy-compounds isolated as metabolites of hydroxy-and amino-compounds

Compound

$p$-Hydroxybenzoic acid $p$-Hydroxybenzamide $p$-Cresol p-Hydroxyphenylalanine (tyrosine) $\boldsymbol{p}$-Hydroxybenzenesulphonamide $p$-Aminobenzenesulphonamide

$m$-Cresol

m-Aminobenzenesulphonamide

o-Hydroxybenzoic acid $o$-Cresol

$o$-Acetoluidide

$o$-Aminobenzènesulphonamide
Oxidation product

3:4-Dihydroxybenzoic acid 3:4-Dihydroxybenzoic acid 3:4-Dihydroxytoluene*

3:4-Dihydroxyphenylalanine 3:4-Dihydroxybenzenesulphonamide 4-Amino-3-hydroxybenzenesulphonamide

3:4-Dihydroxytoluene*

3-Amino-4-hydroxybenzenesulphonamide

2:5-Dihydroxybenzoic acid 2:5-Dihydroxytoluene

Derivative of 2-amino-3-hydroxytoluene

2-Amino-3-hydroxybenzenesulphonamide (?)

$\begin{aligned} & \text { Animal or } \\ & \text { enzyme }\end{aligned}$
Rabbit
Rabbit
Tyrosinase
Tyrosinase
Rabbit
Rabbit

Tyrosinase

Rabbit

Rat

Dog

Dog

Rabbit

\section{Reference}

Present communication Present communication Pugh \& Raper (1927)

Raper (1926)

Williams (1941)

Thorpe, Williams \&

Shelswell (1941);

Williams (1946)

Pugh \& Raper (1927)

Dobson \& Williams (1946)

Lutwak-Mann (1943)

Preusse (1881)

Jaffe \& Hilbert (1888)

Williams (1945)

* Preusse (1881) did not detect these oxidation products in the dog. 


\title{
REFERENCES
}

Balls, A. K. \& Lineweaver; H. (1939). J. biol. Chem. 130, 669.

Baumann, E. \& Herter, E. (1877). Hoppe-Seyl. Z. 1, 244.

Bray, H. G., Neale, F. C. \& Thorpe, W. V.(1946a). Biochem. J. 40, 134.

Bray, H. G., Neale, F. C. \& Thorpe, W. V. (1946b). Biochem. $J .40,406$.

Bruce, H. M. \& Parkes, A. S. (1946). J. Hyg., Camb., 44, 501.

Dobson, F. \& Williams, R. T. (1946). Biochem. J. 40, 215.

Fischer, E. (1908). Ber. dtsch. chem. Ges. 41, 2880.

Hartmann, O. (1877). J. prakt. Chem. 16, 39.

Jaffe, M. \& Hilbert, P. (1888). Hoppe-Seyl. Z. 12, 295.

Lutwak-Mann, C. (1943). Biochem. J. 37, 246.

Marfori, P. (1897). Ann. Chim. Farm. 24, 481.

Northrop, J. H. (1932). J. gen. Physiol. 16, 53.
Power, F. W. \& Sherwin, C. P. (1927). Arch. intern. Med. 39, 60.

Preusse, C. (1878). Hoppe-Seyl. Z. 2, 329.

Preusse, C. (1881). Hoppe-Seyl. Z. 5, 57.

Pugh, C. E. M. \& Raper, H. S. (1927). Biochem. J. 21, 1370.

Quick, A. J. (1932a). J. biol. Chem. 96, 83.

Quick, A. J. (1932b). J. biol. Chem. 97, 403.

Raper, H. S. (1926). Biochem. J. 20, 735.

Schotten, C. (1882). Hoppe-Seyl. Z. 7, 23.

Sherwin, C. P. (1918). J. biol. Chem. 36, 309.

Thorpe, W. V., Williams, R. T. \& Shelswell, J. (1941). Biochem. J. 35, 52.

Williams, R. T. (1938). Biochem. J. 32, 878.

Williams, R. T. (1941). Biochem. J. 35, 1169.

Williams, R. T. (1945). Biochem. J. 39, xl.

Williams, R. T. (1946). Biochem. J. 40, 219.

\section{The Action of Formaldehyde on the Gystine Disulphide Linkages of Wool \\ 2. THE CONVERSION OF SUBFRACTION A OF THE COMBINED CYSTINE INTO COMBINED LANTHIONINE AND DJENKKOLIC ACID AND SUBFRACTION B INTO COMBINED THIAZOLIDINE-4-CARBOXYLIC ACID}

\author{
By W. R. MIDDLEBROOK AND H. PHILLIPS, Wool Industries Research Association, \\ Torridon, Headingley, Leeds, 6
}

\section{(Received 25 November 1946)}

Fraction $(\mathrm{A}+\mathrm{B})$ of the combined cystine of wool reacts with $\mathrm{NaHSO}_{3}$ to give cysteine and $S$-cystinesulphonate side-chains: those derived from subfraction A revert to disulphide when the bisulphited wool is rinsed with water, whereas the cysteine and $S$-cysteinesulphonate side-chains derived from subfraction B are water-stable (Elsworth \& Phillips, 1941 ; Middlebrook \& Phillips, 1942a). When wool is treated at $70^{\circ}$ with solutions of formaldehyde at a $\mathrm{pH}$ between 5 and 7, half of the sulphur of subfraction $\mathrm{B}$ is converted into combined thiazolidine-4-carboxylic acid (Middlebrook \& Phillips, 1942b). Since subfraction $B$ reverts to disulphide when this formalized wool is boiled with $\mathrm{H}_{3} \mathrm{PO}_{4}$, it is possible that the formaldehyde condenses with the thiol group produced by the hydrolysis of the disulphide group (-SS- $\rightleftharpoons-\mathrm{SH}+-\mathrm{SOH}$ ), but leaves the sulphenic acid group unchanged. The sulphenic acid group may condense with an adjacent imino group forming an isothiazole ring (McClelland \& Warren, 1930; Middlebrook \& Phillips, 1942b), but may be liberated when the wool is boiled with $\mathrm{H}_{3} \mathrm{PO}_{4}$.

Stoves (1943) boiled keratin fibres with solutions of formaldehyde and from an examination of their load-extension curves suggested that some of the cystine cross-linkages had been converted into djenkolic cross-linkages (: $\mathrm{CHCH}_{2} \mathrm{SCH}_{2} \mathrm{SCH}_{2} \mathrm{CH}$ :). We have treated wool under similar conditions to those used by Stoves (1943), but find that it does not contain combined djenkolic acid; subfraction $\mathbf{A}$ is converted into lanthionine and subfraction $B$ into thiazolidine-4-carboxylic acid. On the other hand, when fraction $(\mathrm{A}+\mathrm{B})$ is reduced with thiolacetic acid (Middlebrook \& Phillips, 1942b), and the reduced wool is treated with formaldehyde, combined djenkolic acid arises from subfraction $A$, whilst subfraction $B$ is converted into combined thiazolidine4-carboxylic acid.

When wool in which fraction $(A+B)$ has been reduced is treated with methylene di-iodide, only subfraction $\mathbf{A}$ is converted into combined djenkolic acid; both subfractions are, however, cross-linked, when the reduced wool is treated with ethylene dibromide.

\section{METHODS}

Materials and analytical methods. The wool used (80's quality; total-S, 3.65; disulphide-S, $3 \cdot 06 \%$ ) was in the form of a knitted fabric which had been cleaned with soap, rinsed in water, extracted with ethanol and finally rinsed in water.

Unless otherwise stated, the treated and untreated wools were hydrolyzed under reflux in $5 \mathrm{~N}-\mathrm{HCl}$ for $4 \mathrm{hr}$. The 